\title{
A Very Elderly Case of Idiopathic Superior Lumbar Hernia Showing Atypical Symptoms
}

Satoshi YAMAGUCHI $^{* 1}$, Giichiro OHNO ${ }^{* 2}$

[Abstract] We report a very elderly case of an idiopathic superior lumbar hernia requiring emergency surgery because of delayed diagnosis owing to atypical symptoms. The patient was a 101-year-old woman who was hospitalized owing to right lumbago, which was estimated to be caused by complicated osteoporosis. On the 3rd day after admission, her lumbago suddenly worsened and was associated with nausea and the urge to vomit, and a soft bulge appeared in her right lower back area. Computed tomography revealed a prolapse of the intestinal tract through the posterolateral abdominal wall. Diagnosis of a lumbar hernia was established, and the patient underwent emergency abdominal repair surgery. General anesthesia was performed, and her hemodynamic state was stable during surgery despite her very advanced age. Although intestinal necrosis and peritonitis were suspected, they were not diagnosed. The operative view was a superior lumbar hernia, and incarceration was repaired without any complication. There have been no signs of recurrence. Lumbar hernia is a very rare disease with atypical symptoms such as lumbago and lumbar bulge. The diagnosis therefore tends to be delayed, and emergency surgery is frequently required for incarceration of the intestinal tract. We suggest that anesthesiologists should keep this disease in mind during daily clinical consultations.

Key Words : Lumbar hernia, Incarceration, Lumbago, Dorsal bulge, Very elderly case

\section{Introduction}

The symptoms of ventral hernias are generally abdominal bulge or pain, and they are not difficult to diagnose. However, lumbar hernias, which are a very rare type of ventral hernias, arise through dorsal abdominal wall defects and show atypical symptoms such as lower back bulge and lumbago ${ }^{1)}$. Therefore, these often require emergency surgery because of a

Received Jul. 10, 2014 ; Accepted Sep. 24, 2014

${ }^{* 1}$ Department of Anesthesia, Tokatsu Hospital

${ }^{* 2}$ Department of Surgery, Tokatsu Hospital delay in diagnosis if accompanied by an incarcerated colon ${ }^{2)}$.

Herein, we present the case of a very elderly female with an idiopathic superior lumbar hernia that required emergency surgery because of delayed diagnosis owing to atypical symptoms and discrimination with complicated osteoporosis.
Corresponding author : Satoshi Yamaguchi Department of Anesthesia, Tokatsu Hospital 409 Shimohanawa, Nagareyama, Chiba 270-0174, Japan 


\section{Case report}

The patient was a 101-year-old woman (height 130 $\mathrm{cm}$, weight $38 \mathrm{~kg}$ ) who had suffered from osteoporosis and spinal canal stenosis for approximately 10 years. Non-steroidal anti-inflammatory drugs (NSAIDs) and etidronate were administered in the outpatient clinic. She had no past history of abdominal or lumbar surgery or external injuries.

The patient was hospitalized with exacerbation of right lumbago, which was thought to be caused by the underlying disease. On admission, physical examination did not reveal any abnormality in her lower back region. At first, during physiotherapy, additional NSAIDs and elcatonin were administered.

On the 3rd day after admission, the right lumbago worsened, and was associated with nausea and the urge to vomit. A protruding semispherical soft bulge with a diameter of approximately 9-10 cm was found in her lower back, and this region was also very painful. Abdominal X-rays revealed an ileus image (Fig. 1). Computed tomography (CT) of the abdomen also revealed a prolapse of the intestinal tract through the right dorsal abdominal wall(Fig.2). The patient was consequently diagnosed with a lumbar hernia. Manual manipulation of the hernia was not possible, and she was therefore scheduled for emergency abdominal repair surgery under general anesthesia.

Preoperative laboratory data revealed slight inflammatory changes and altered renal function [blood urea nitrogen $(\mathrm{BUN}), 32.0 \mathrm{mg} / \mathrm{d} l$; creatinine(CRE), $1.3 \mathrm{mg} / \mathrm{d} l$; C-reactive protein (CRP), $2.8 \mathrm{mg} / \mathrm{d} l$; white blood cell count (WBC) , 9,800/ $\mu l$ l. On admission to the operating theatre, her blood pressure was 155/77 mmHg and her heart rate was 80 beats/min. We selected rapid sequence induction as the anesthetic method ; it was performed without any issues.

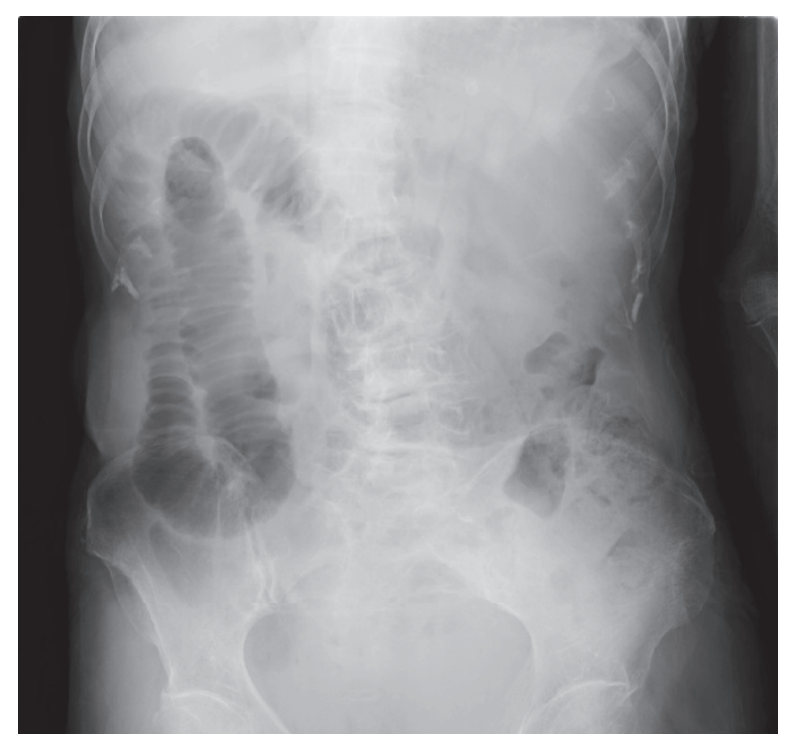

Fig. 1 Preoperative abdominal X-ray showing the ileus image (herring bone appearance)

Anesthesia was maintained with sevoflurane, continuous infusion of remifentanil, and $60 \%$ oxygen.

The surgery was performed through an opening in the abdominal cavity in the left lateral decubitus position. The hernia orifice was easily located. A superior lumbar hernia was identified. There were no findings of peritonitis or necrosis of the intestinal tract. After removing the incarcerated ascending colon, the orifice was closed and reinforced. The duration of surgery was $65 \mathrm{~min}$.

We were extremely concerned about deterioration of the patient's hemodynamic state during anesthesia because of her advanced age and unstable general status. However, the patient's vital signs remained stable and we did not use catecholamines during surgery. Postoperatively, all anesthetics were discontinued and sufficient spontaneous respiration occurred rapidly. However, her level of consciousness remained uncertain, so she was monitored in a high care unit until the following day. From this point, her postoperative course was uncomplicated, and the 


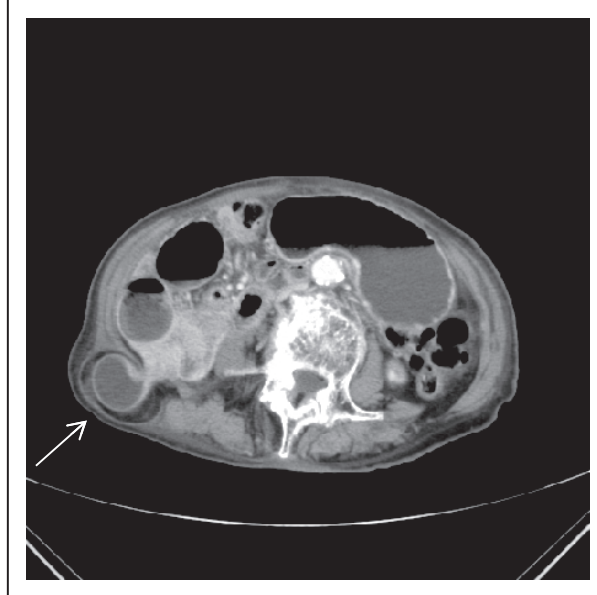

a

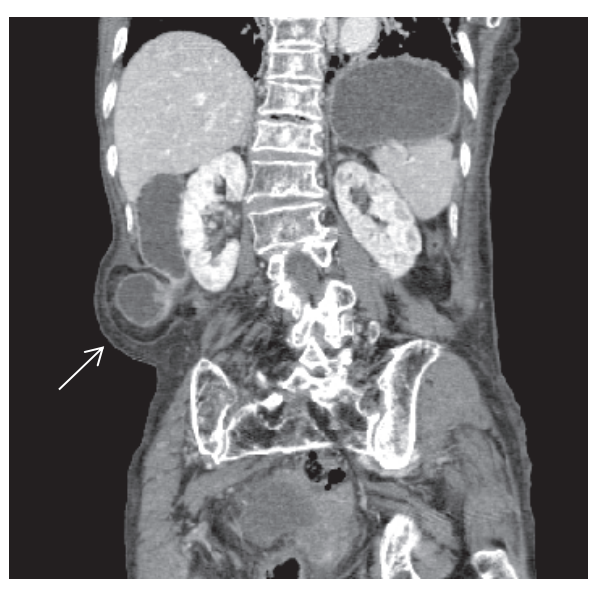

$\mathrm{b}$

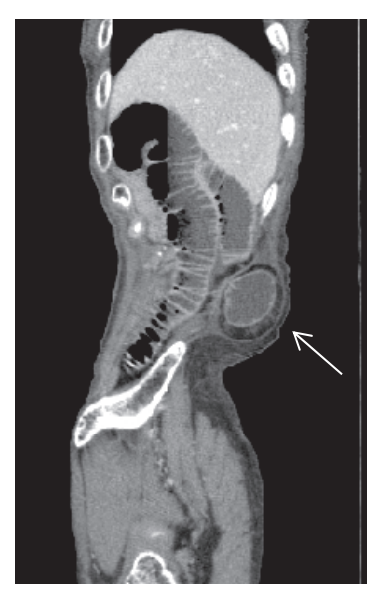

c

Fig. 2 Abdominal computed tomography (CT) images (a, axial view ; b, coronal view ; c, sagittal view) showing the prolapse of the intestinal tract through the right dorsal abdominal wall (white arrows)

lumbago disappeared. The patient was discharged on the 30th postoperative day. There have been no signs of a recurrence of the lumbar hernia.

\section{Discussion}

There are two anatomically weak areas in the dorsal abdominal wall : the superior lumbar triangle (Grynfeltt-Lesshaft space) and the inferior lumbar triangle(Petit's triangle). Hernias arising from these vulnerable abdominal wall areas are rare. They are called superior and inferior lumbar hernia, respectively ${ }^{3)}$. The orifice of the superior lumbar hernia is formed medially by the quadratus lumborum muscle, laterally by the internal abdominal oblique muscle, and superiorly by the 12 th rib. A superior lumbar hernia usually arises on the left side, and a right superior lumbar hernia, as in this present case, has not been reported previously ${ }^{4)}$.

The majority of hernias are acquired, and classified as either idiopathic or traumatic. Idiopathic hernias are caused by an increase in abdominal pressure associated with obesity, scoliosis, and chronic obstructive pulmonary disease $(\mathrm{COPD})^{5)}$. Traumatic hernias are caused by surgery and injury ${ }^{6)}$. Elderly women are vulnerable to hernias because they often have a weak abdominal wall and reduced mobility of the intestinal tract. Until this date, however, there had been no case reports on patients over 100 years of age.

The main symptoms are a protruding bulge in the lower back area and lumbago that is often accompanied by an incarcerated intestinal tract. The contents of a hernia frequently include adipose tissue near the intestinal tract, and patients are often diagnosed with a dorsal lipoma ${ }^{7)}$. In the present case, the primary atypical symptoms were lumbago and a dorsal bulge that only emerged later. It would be advisable in elderly patients to regularly examine the lower dorsal area and eliminate the possibility of a dorsal lipoma or orthopedic chronic lower back pain. This would prevent an extended delay in treatment of lumbar hernia and would also avoid worsening of the patient's general condition ${ }^{1)}$. An abdominal CT scan would also help in diagnosis ${ }^{8}$.

There are often difficulties associated with the surgical approach to a hernia orifice ${ }^{9)}$. In the present case, however, the open approach was the ideal treat- 
ment option. Recent studies have demonstrated the advantages of a laparoscopic repair for a low inva$\operatorname{sion}^{10)}$. General anesthesia is usually the preferred anesthetic management, but high-risk cases have been managed under regional and infiltration anesthesia $^{4)}$. In our case, surgery was uneventful without findings of intestinal necrosis or peritonitis, and the patient's condition was also stable despite her advanced age. Furthermore, the postoperative course was uncomplicated and postoperative pain was minimal. However, in case of an emergency surgery for a very elderly patient with probable complications of intestinal necrosis or peritonitis, careful anesthetic management is necessary in view of the deterioration of hemodynamic state during anesthesia.

In conclusion, we present an elderly patient with a rare idiopathic superior lumbar hernia that required emergency surgery. Symptoms such as lumbago and lumbar bulge are atypical, so diagnosis is often delayed and emergency surgery is frequently required to repair an incarcerated intestinal tract. We propose that anesthesiologists keep this disease in mind during clinical consultations to enable early detection of atypical symptoms. In addition, radiographic examinations such as CT of the abdomen would help in the diagnosis.

The authors received permission from the patient and families to publish this case report.

\section{Acknowledgments}

The authors thank Enago(http://www.enago.jp) for the English language review.

\section{References}

1) Stamatiou D, Skandalakis JE, Skandalakis LJ, et al. : Lumbar hernia : surgical anatomy, embryology, and technique of repair. Am Surg 75 : 202-207, 2009

2) Petersen K, Snikeris J, Hall TS : Bleichner's hernia-lumbar hernia. Am J Case Rep 14 : 26-29, 2013

3) Cavallaro G, Sadighi A, Paparelli C, et al. : Anatomical and surgical considerations on lumbar hernias. Am Surg $75:$ 1238-1241, 2009

4) Cavallaro A, De Toma G, Cavallaro G : Lumbar hernia : a short historical survey. Ann Ital Chir $83: 451-454,2012$

5) Xu T, Zhang S, Wang H, et al. : Lumbar hernia associated with chronic obstructive pulmonary disease (COPD). Pak J Med Sci 29 : 874-876, 2013

6) Esposito TJ, Fredorak I : Traumatic lumbar hernia : case report and literature review. J Trauma 37 : 123-126, 1994

7) Mingolla GP, Amelio G : Lumbar hernia misdiagnosed as a subcutaneous lipoma : a case report. J Med Case Rep 3 : 9322, 2009

8) Moreno-Egea A, Baena EG, Calle MC, et al. : Controversies in the current management of lumbar hernias. Arch Surg $142: 82-88,2007$

9) Cavallaro G, Sadighi A, Miceli M, et al. : Primary lumbar hernia repair : the open approach. Eur Surg Res 39 : 8892, 2007

10) Suarez S, Hernandez JD : Laparoscopic repair of a lumbar hernia : report of a case and extensive review of the literature. Surg Endosc 27 : 3421-3429, 2013 


\title{
非典型的症状を呈した超高齢者特発性上腰ヘルニア症例
}

\author{
山口 聡*1, 大野義一郎*2 \\ *1 東葛病院麻酔科 \\ *2 東葛病院外科
}

101歳の超高齢女性が持病である骨粗鬆症と変形性腰椎症による腰痛の増悪の診断で入院し，その3日 後に腰部の腫瘤と腸閉塞症状を呈した. CT所見において後腹壁からの腸管の脱出を認め, 腰へルニア と診断され緊急開腹術が施行された。手術所見は特発性上腰ヘルニアであり，腸管壊死や腹膜炎は認め ずに修復され，再発も認めず術後腰痛も消失した．腰ヘルニアは腰背部腹壁の脆弱部位から発症するま れな疾患であるが，腰痛や腰部腫瘤といった非典型的な症状によりしばしば診断が遅延する．高齢女性 に多く, ヘルニア内容が腸管の場合は腸閉塞や腸管壊死, 腹膜炎から緊急開腹術となる可能性が高く, 麻酔科医としても念頭に入れておくべき疾患と思われる.

キーワード: 腰ヘルニア, 腸管陷頓, 腰痛, 腰背部腫瘤, 超高齢者

The Journal of Japan Society for Clinical Anesthesia Vol.35 No.1, 2015 